Effects of Temperature and Plant Growth Regulators on the Scale Propagation of Lilium davidii

\section{var. unicolor}

\author{
Nan Tang \\ Key Laboratory of Qinghai Province for Landscape Plants Research, \\ Plateau Flower Research Centre, Qinghai University, Xining 810016, \\ China; and State Key Laboratory of Plateau Ecology and Agriculture, \\ Qinghai University, Xining 810016, China
}

\section{Xiuting Ju, Yafan Hu, Rulong Jia, and Daocheng Tang \\ Key Laboratory of Qinghai Province for Landscape Plants Research, Plateau Flower Research Centre, Qinghai University, Xining 810016, China}

Additional index words. bulblet, Lanzhou lily, scale differentiation, temperature screening, vegetative propagation

\begin{abstract}
Scale propagation is a cost-effective and time-saving reproduction method for lily bulb production. The effects of different incubation temperatures and plant growth regulators on the scale propagation of Lilium davidii var. unicolor were investigated. The results showed that temperature influences the scale rot incidence rate, speed of scale differentiation and bulblet formation, as well as the size of bulblets. The optimum temperature for scale propagation of $L$. davidii var. unicolor was $30^{\circ} \mathrm{C}$. Scales incubated at $30{ }^{\circ} \mathrm{C}$ showed a lower rot incidence and faster differentiation and produced larger bulblets. The application of gibberellic acid $\left(\mathrm{GA}_{3}\right)$, 1-naphthaleneacetic acid (NAA), and 6-benzylaminopurine (6-BA) had no significant influence on the differentiation rate of scales. $\mathrm{GA}_{3}$ application reduced the incidence rate of scale rot. However, treatment with $50 \mathrm{mg} / \mathrm{L}$ NAA and $2 \mathrm{mg} / \mathrm{L}$ 6-BA significantly increased the rot incidence rate in the second week of propagation. Both treatments with $100 \mathrm{mg} / \mathrm{L} \mathrm{NAA}$ and $100 \mathrm{mg} / \mathrm{L} \mathrm{GA}$ produced a higher number of bulblets than their controls after 6 weeks of incubation. $\mathrm{GA}_{3}$ at 100 and $150 \mathrm{mg} / \mathrm{L}$ increased the diameter of bulblets, resulting in more large bulblets (grade 1) and fewer small bulblets (grade 3). 6-BA did not facilitate propagation by scaling.
\end{abstract}

Lilium davidii var. unicolor is one of the most important bulbous plants because of its showy flowers and edible and medicinal values. This plant is native to China and grown widely around the world. L. davidii var. unicolor is quite suitable for growing in cold, dry, and longday areas. In the cold arid mountain area of northwestern China, the planted acreage of $L$. davidii var. unicolor is $\approx 20,000$ ha. The Qilihe district of Lanzhou city (Gansu Province, China)

Received for publication 12 Feb. 2020. Accepted for publication 27 Mar. 2020.

Published online 6 May 2020

We are thankful for the foundation from Science and Technology Department of Qinghai Province (2018-NK-102) and the support from National Natural Science Foundation of China (31660582). The study was supported also by the Key Laboratory of Landscape Plants of Qinghai Province and High Level Innovative Thousand Talents Program of Qinghai Province (2016).

D.T. is the corresponding author. E-mail: tangdaocheng6333@163.com.

This is an open access article distributed under the CC BY-NC-ND license (https://creativecommons.org/ licenses/by-nc-nd/4.0/).
Tuyl (1984) discussed the effects of temperature on leaf emergence of scale bulblets and plant development during scale propagation of $L$. longiflorum. An efficient production method for variegated $L$. longiflorum from scales has been established (Matsuo et al., 1989). A preliminary study investigated the optimum growing medium and growth regulators for scale propagation of hybrid lilies such as the Asiatic lily 'Pollyanna' (Dilta et al., 2000). Marinangeli et al. (2003) studied bulblet differentiation of $L$. longiflorum and found that the middle scales are the ideal starting material for experimental uses involving scale propagation. Bulblet formation and development are crucial for bulb production of lilies by scaling. Wu et al. (2016) investigated the effects of humic acid on bulblet swelling and carbohydrate metabolism in Lilium oriental hybrids.

Plant growth regulators have important roles in plant growth and development, such as promoting flowering, prolonging vase life, inhibiting abscission, preventing/breaking bud dormancy, controlling growth, and overcoming bud deterioration (Cleland, 2010; Finkelstein, 2010; Khan et al., 2007; Prat, 2010; Woodger et al., 2010; Xu et al., 2007). Plant growth regulators have been widely used in the vegetative propagation of bulbous ornamentals (Gaspar et al., 1996; Hanks and Rees, 1977; Kawa-Miszczak et al., 1992). GA 3 is beneficial for increasing plant height, stalk length, and leaf fresh weight, and it results in maximum vegetative yield (Aklade et al., 2009). Dicks et al. (1973) reported that $\mathrm{GA}_{3}$ significantly affected the pedicel length of the first flower of lily. The optimum concentrations of NAA and 6-BA are important for in vitro propagation of lily. BA promoted the formation of bulblets on scales and stem elongation in bulblets formed on scales of L. formolongi (Ishimori and Niimi, 2005; Ishimori et al., 2007). A combined application of $1.5 \mathrm{mg} / \mathrm{L} \mathrm{NAA}$ and $2 \mathrm{mg} / \mathrm{L}$ BA significantly induced bulblet regeneration in oriental hybrid lily (Kumar et al., 2008). However, the application of exogenous ABA was shown to inhibit the formation of scale leaves in the oriental hybrid lily 'Siberia', whereas endogenous ABA synthesis was inhibited (Zhao et al., 2010). Therefore, it is important to know how to use plant growth regulators to induce the formation and promote the growth of bulblets.

Based on previous studies, this study aimed to 1) screen the optimum temperature for bulblet formation and development during scale propagation and 2) explore the effects of three plant growth regulators $\left(\mathrm{GA}_{3}, \mathrm{NAA}\right.$, and 6-BA) on the scale propagation of $L$. davidii var. unicolor. Although the scale propagation method is not new for lilies, no complete study has discussed the influence of incubation temperature and plant growth regulators on the incidence rate of scale rot, scale differentiation potential, and bulblet development. The results of this study will provide theoretical evidence for the scale propagation of $L$. davidii var. unicolor, which is important in the mass propagation of lily. 


\section{Materials and Methods}

Plant materials. Fresh bulbs of $L$. davidii var. unicolor $(150 \mathrm{~g} \pm 10 \mathrm{~g})$ were collected in Mar. 2018 from the Qilihe area of Lanzhou, Gansu Province, China. The dormancy of these bulbs was broken during the cold winter. Bulbs were placed at room temperature for 1 week before scaling. Scales were removed from bulbs and sorted into three groups based on their position on the parent bulb: external scale (1-2 layers), middle scale (3-4 layers), and inner scale (5-7 layers). Middle scales were used in this study (Marinangeli et al., 2003). Healthy scales without mechanical damage were selected. Scales were washed in tap water and immersed in $0.5 \%$ thiophanate-methyl for $30 \mathrm{~min}$. The peat (Floragard Vertriebs-GmbH, Oldenburg, Germany) used as medium was sterilized by $125 \times$ formaldehyde and $100 \mathrm{~g}$ of $50 \%$ thiophanatemethyl per cubic meter of peat.

Effects of temperature on scale propagation. To determine the optimum temperature for propagation by scaling, a single-factor completely randomized trial was performed. Scales were incubated at 20,25 , and $30{ }^{\circ} \mathrm{C}$ in peat in separate cultivation beds. There was a heater wire at the bottom of each bed, and the temperature was controlled by an intelligent temperature controller. Prepared scales were mixed with an equal volume of peat, placed in a cultivation bed, and covered with $5 \mathrm{~cm}$ of peat. Plastic film with holes was used to wrap the bed to preserve moisture and prevent the accumulation of ethylene. The total incubation period was 6 weeks, and data were collected every week with three replicates for each treatment. One hundred scales were collected randomly each time. The scales showing obvious brown spots (diameter $>1.0 \mathrm{~cm}$ ) and rotten scales were counted. The number of differentiated scales and number of bulblets on each scale were recorded. Sample scales, except those that were rotten, were put back in the cultivation bed. At the end of incubation, 30 bulblets were collected randomly from each treatment and were classified into three grades: $1=$ large (diameter $>7.0 \mathrm{~mm}$ ); $2=$ middle (diameter $3.0-6.9 \mathrm{~mm}$ ); and $3=$ small (diameter $<3.0 \mathrm{~mm}$ ). Three repeats were performed for each treatment.

Effects of plant growth regulators on scale propagation. Effects of different concentrations of $\mathrm{GA}_{3}$, NAA, and 6-BA on the scale propagation of $L$. davidii var. unicolor were investigated in this study. Concentrations of plant growth regulators were set as follows: $\mathrm{GA}_{3}(0,50,100,150 \mathrm{mg} / \mathrm{L}), \mathrm{NAA}$ $(0,50,100,150 \mathrm{mg} / \mathrm{L})$, and 6-BA $(0,1,2,3$ $\mathrm{mg} / \mathrm{L})$. Each treatment was replicated three times, and 100 scales were used in each replicate. Scales were soaked in a solution of plant growth regulators for $30 \mathrm{~min}$, and those treated in the same solvent without plant growth regulators were used as controls. Scales of each treatment were put into a separate mesh bag with an equal volume of sterilized peat, placed in a cultivation bed, and covered following the methods already outlined. According to a preliminary study, during this experiment, scales were incubated at $30{ }^{\circ} \mathrm{C}\left( \pm 1{ }^{\circ} \mathrm{C}\right)$ with a relative water content of $60.0 \%$. All replicates were randomized over the cultivation bed. The scales showing obvious brown spots (diameter $>1.0 \mathrm{~cm}$ ) and rotten scales were counted every week to calculate the incidence rate. The rotten scales were removed after inspection. The numbers of differentiated scales and bulblets on each scale were recorded. After 6 weeks, bulblets were graded according to the grading standard mentioned.

Statistical analyses. The incidence rate was numerically defined as the number of new cases of scale rot within a time period as a proportion of the number of scales at risk for rot. It was calculated as the total number of rotten scales and scales showing obvious brown spots divided by the total number of scales at the moment. The percentage data were arcsintransformed before analysis. PASW statistics 18 was used for data analysis and the standard error of the mean was calculated. An analysis of variance was performed. Significant differences between treatments were assessed using the least significant difference test at $P<0.05$.

\section{Results}

Effects of temperature on scale propagation. Scales incubated at $20^{\circ} \mathrm{C}$ presented a distinct peak in rot at the beginning of cultivation. In the second week, the incidence rate of scale rot at $20^{\circ} \mathrm{C}(36.67 \%)$ was significantly higher than those of scales at $25^{\circ} \mathrm{C}(9.0 \%)$ and $30^{\circ} \mathrm{C}$ $(6.67 \%)$. There was no significant difference in the scale rot incidence between 25 and $30{ }^{\circ} \mathrm{C}$ (Fig. 1).

Scales underwent differentiation as soon as the propagation procedure began. Bulblets formed rapidly during the first 3 weeks (Fig. 2). Scales cultured at $20{ }^{\circ} \mathrm{C}$ differentiated slower than those cultured at 25 and $30{ }^{\circ} \mathrm{C}$. A total of $90.00 \%( \pm 4.36)$ of scales incubated at $30{ }^{\circ} \mathrm{C}$ formed bulblets at the third week, whereas the percentage was only $68.00 \%( \pm 1.53)$ for scales at $20{ }^{\circ} \mathrm{C}$. After 6 weeks, the differentiation rate of scales at $30{ }^{\circ} \mathrm{C}$ was $90.67 \%( \pm 3.67)$. There was no significant improvement in scale differentiation between incubation for 3 weeks or 6 weeks. The differentiation rate of scales incubated at $25{ }^{\circ} \mathrm{C}$ was $82.33 \%( \pm 6.33)$ at 3 weeks; from that point on, there was no significant variation in the differentiation rate.

Bulblets developed faster at 30 and $25^{\circ} \mathrm{C}$ than at $20{ }^{\circ} \mathrm{C}$. During the first 3 weeks, the number of bulblets that grew on scales incubated at 30 and $25^{\circ} \mathrm{C}$ was significantly higher than that on bulbs grown at $20{ }^{\circ} \mathrm{C}$ (Fig. 3). However, after 4 weeks, the number of bulblets per scale presented no significant variation among the different temperature treatments.

After 6 weeks of scale propagation, bulblets of each treatment were collected for evaluation of bulblet size. Bulblets were divided into three grades according to their diameter. In general, the middle bulblets (grade 2) accounted for more than $60 \%$ of the total amount of bulblets regardless of which temperature treatment was applied. Compared with the 20 and $25^{\circ} \mathrm{C}$ treatments, scales at $30{ }^{\circ} \mathrm{C}$ produced more large bulblets (grade 1) and fewer small bulblets (grade 3) (Table 1).

Effects of plant growth regulators on scale propagation. Scales were treated with $\mathrm{GA}_{3}, 6-\mathrm{BA}$, and NAA at different concentrations before incubation. According to the results of the temperature screening, all treatments were controlled at $30{ }^{\circ} \mathrm{C}$. The results showed that NAA and 6-BA at different concentrations were not conducive to reducing the incidence rate of scale rot during scale propagation (Table 2). At the second week of incubation, treatment with $50 \mathrm{mg} / \mathrm{L}$

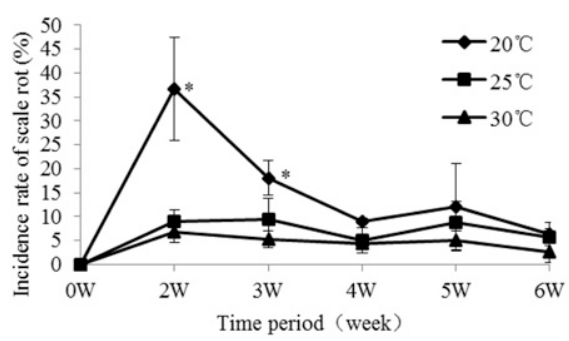

Fig. 1. Effects of different temperatures on the incidence rate of scale rot. Values represent the mean of three replicates. Data were arcsinetransformed before significance analysis. Bars indicate the SE. *Significant differences at $P<0.05$.

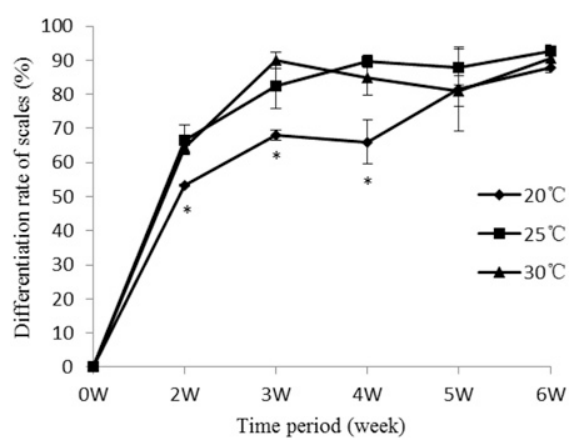

Fig. 2. Effects of different temperatures on differentiation rate of scales. Values represent the mean of three replicates. Bars indicate the SE. * Significant differences at $P<0.05$.

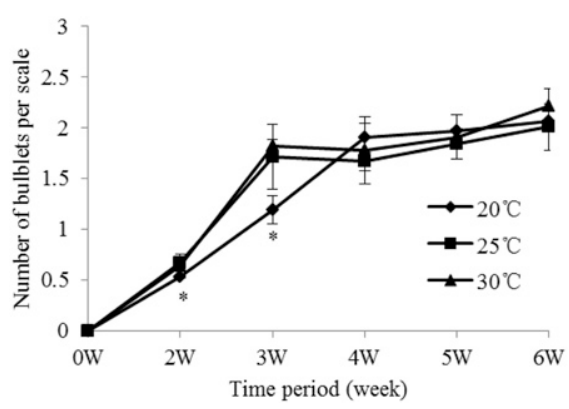

Fig. 3. Effects of different temperatures on the number of bulblets per scale. Values represent the mean of three replicates. Bars indicate the SE. * Significant differences at $P<0.05$. 
Table 1. Variation of bulblet size among different temperature treatments.

\begin{tabular}{|c|c|c|c|}
\hline Temperature $\left({ }^{\circ} \mathrm{C}\right)$ & Grade 1 (diameter $\geq 7 \mathrm{~mm})$ & Grade 2 (diameter $4 \mathrm{~mm}$ to $<7 \mathrm{~mm}$ ) & Grade 3 (diameter $<4 \mathrm{~mm}$ ) \\
\hline 20 & $17.74 \pm 4.61 \mathrm{~b}$ & $62.96 \pm 8.27 \mathrm{a}$ & $19.30 \pm 3.73 \mathrm{a}$ \\
\hline 25 & $16.61 \pm 10.57 \mathrm{~b}$ & $61.76 \pm 4.98 \mathrm{a}$ & $21.63 \pm 6.66 \mathrm{a}$ \\
\hline 30 & $31.35 \pm 4.50 \mathrm{a}$ & $62.87 \pm 4.48 \mathrm{a}$ & $5.78 \pm 3.77 \mathrm{~b}$ \\
\hline
\end{tabular}

The different lowercase letters indicate significant differences at $P<0.05$ level.

Table 2. Effects of different plant growth regulators on the incidence of scale rot during the propagation process.

\begin{tabular}{|c|c|c|c|c|c|c|}
\hline & \multirow[b]{2}{*}{ Treatment } & \multicolumn{5}{|c|}{ Incidence rate $(\%)( \pm \mathrm{SE})$} \\
\hline & & $2 \mathrm{wk}$ & $3 \mathrm{wk}$ & $4 \mathrm{wk}$ & $5 \mathrm{wk}$ & $6 \mathrm{wk}$ \\
\hline \multirow[t]{4}{*}{$\overline{\mathrm{GA}_{3}}$} & CK & $3.67 \pm 2.49 \mathrm{a}$ & $3.13 \pm 0.78 b$ & $8.20 \pm 1.24 \mathrm{a}$ & $1.74 \pm 1.67 \mathrm{a}$ & $0.00 \pm 0.00 \mathrm{~b}$ \\
\hline & $50 \mathrm{mg} / \mathrm{L}$ & $2.33 \pm 0.94 \mathrm{a}$ & $5.86 \pm 1.31 \mathrm{a}$ & $0.75 \pm 1.06 \mathrm{~b}$ & $0.00 \pm 0.00 \mathrm{a}$ & $0.00 \pm 0.00 \mathrm{~b}$ \\
\hline & $100 \mathrm{mg} / \mathrm{L}$ & $4.67 \pm 2.49 \mathrm{a}$ & $0.35 \pm 0.50 \mathrm{c}$ & $0.36 \pm 0.51 \mathrm{~b}$ & $0.00 \pm 0.00 \mathrm{a}$ & $0.75 \pm 0.53 \mathrm{a}$ \\
\hline & $150 \mathrm{mg} / \mathrm{L}$ & $6.67 \pm 2.05 \mathrm{a}$ & $0.73 \pm 0.52 \mathrm{c}$ & $0.00 \pm 0.00 \mathrm{~b}$ & $1.52 \pm 1.44 \mathrm{a}$ & $0.00 \pm 0.00 \mathrm{~b}$ \\
\hline \multirow[t]{4}{*}{ NAA } & $\mathrm{CK}$ & $4.00 \pm 0.82 b$ & $0.00 \pm 0.00 \mathrm{~b}$ & $3.19 \pm 1.50 \mathrm{a}$ & $1.12 \pm 0.91 \mathrm{ab}$ & $0.00 \pm 0.00 \mathrm{a}$ \\
\hline & $50 \mathrm{mg} / \mathrm{L}$ & $22.67 \pm 2.05 \mathrm{a}$ & $2.63 \pm 1.86 \mathrm{a}$ & $0.00 \pm 0.00 \mathrm{~b}$ & $1.18 \pm 0.87 \mathrm{ab}$ & $0.00 \pm 0.00 \mathrm{a}$ \\
\hline & $100 \mathrm{mg} / \mathrm{L}$ & $3.67 \pm 0.94 b$ & $0.35 \pm 0.50 \mathrm{ab}$ & $0.71 \pm 0.50 \mathrm{ab}$ & $2.92 \pm 1.91 \mathrm{a}$ & $0.37 \pm 0.52 \mathrm{a}$ \\
\hline & $150 \mathrm{mg} / \mathrm{L}$ & $5.00 \pm 1.63 \mathrm{~b}$ & $0.35 \pm 0.49 \mathrm{ab}$ & $1.10 \pm 1.55 \mathrm{ab}$ & $0.00 \pm 0.00 \mathrm{~b}$ & $0.36 \pm 0.51 \mathrm{a}$ \\
\hline \multirow[t]{4}{*}{$6-\mathrm{BA}$} & CK & $2.33 \pm 1.25 \mathrm{~b}$ & $3.47 \pm 2.18 b$ & $2.12 \pm 1.50 \mathrm{~b}$ & $0.00 \pm 0.00 \mathrm{a}$ & $0.39 \pm 0.55 \mathrm{a}$ \\
\hline & $1 \mathrm{mg} / \mathrm{L}$ & $2.33 \pm 1.53 \mathrm{~b}$ & $2.07 \pm 0.03 \mathrm{~b}$ & $6.76 \pm 0.44 \mathrm{a}$ & $1.16 \pm 0.94 \mathrm{a}$ & $0.40 \pm 0.57 \mathrm{a}$ \\
\hline & $2 \mathrm{mg} / \mathrm{L}$ & $24.00 \pm 4.90 \mathrm{a}$ & $9.82 \pm 3.47 \mathrm{a}$ & $3.53 \pm 1.33 \mathrm{ab}$ & $2.98 \pm 4.21 \mathrm{a}$ & $0.47 \pm 0.66 \mathrm{a}$ \\
\hline & $3 \mathrm{mg} / \mathrm{L}$ & $7.00 \pm 2.94 \mathrm{~b}$ & $5.49 \pm 1.94 \mathrm{ab}$ & $2.69 \pm 2.43 \mathrm{~b}$ & $2.51 \pm 2.04 \mathrm{a}$ & $0.00 \pm 0.00 \mathrm{a}$ \\
\hline
\end{tabular}

The different lowercase letters indicate significant differences at $P<0.05$ level.

NAA and $2 \mathrm{mg} / \mathrm{L}$ 6-BA presented significant negative effects that increased the scale rot incidence rate to $30.67 \%( \pm 6.77)$ and $24.00 \%$ $( \pm 2.83)$, respectively. The incidence of rot in scales treated with different concentrations of $\mathrm{GA}_{3}$ showed no significant difference at 2 weeks. After 2 weeks, the incidence rates of rot in scales that were treated with 100 and $150 \mathrm{mg} / \mathrm{L} \mathrm{GA}_{3}$ decreased significantly; then, they were maintained at a low level. There was no significant difference between the 100 and $150 \mathrm{mg} / \mathrm{L} \mathrm{GA}_{3}$ treatments. The rot incidence rate of scales treated with $50 \mathrm{mg} / \mathrm{L}$ $\mathrm{GA}_{3}$ started decreasing after 3 weeks. However, the rot incidence of CK continued to increase from the beginning of propagation until 4 weeks and was significantly higher than that of the other treatments. The overall variation trend of rot incidence over 6 weeks, indicated that the application of $\mathrm{GA}_{3}$ accelerated the appearance of the inflection point. Scales treated with $\mathrm{GA}_{3}$ showed a significantly lower rot incidence rate than the control, which indicated that the application of $\mathrm{GA}_{3}$ effectively reduced the incidence of rot during the whole scale propagation process.

A comparison of the scale differentiation rate of each week found that scales differentiated rapidly in the first 3 weeks. Compared with the control, $\mathrm{GA}_{3}, \mathrm{NAA}$, and 6-BA at different concentrations showed no significant contribution to the differentiation of scales during the propagation period (Table 3). After 6 weeks, the total number of bulblets obtained from 100 scales that were treated with $100 \mathrm{mg} / \mathrm{L}$ NAA was $161( \pm 10.71)$, which was notably larger than that of the $\mathrm{CK}$ and other treatments. The number of bulblets obtained from the $100 \mathrm{mg} / \mathrm{L} \mathrm{GA}_{3}$ treatment was also significantly higher than that of the CK and other $\mathrm{GA}_{3}$ treatments at 6 weeks (Table 4). Therefore, $100 \mathrm{mg} / \mathrm{L} \mathrm{NAA}$ and $100 \mathrm{mg} / \mathrm{L} \mathrm{GA}_{3}$ could be used to increase the total number of bulblets. Treatments with different concentrations of 6-BA were not conducive to increasing the number of bulblets in scale propagation.
Scales treated with 100 and $150 \mathrm{mg} / \mathrm{L}$ $\mathrm{GA}_{3}$ produced $22.33 \%$ and $18.08 \%$ large bulblets after 6 weeks, respectively; these numbers were significantly more than those of $\mathrm{GA}_{3}$ at $50 \mathrm{mg} / \mathrm{L}$ and $\mathrm{CK}$ (Fig. 4). A low concentration of $\mathrm{GA}_{3}(50 \mathrm{mg} / \mathrm{L})$ was not effective for triggering the growth of bulblets. Treatment with NAA and 6-BA at different concentrations reduced the amount of large bulblets produced. Both $150 \mathrm{mg} / \mathrm{L}$ NAA and $3 \mathrm{mg} / \mathrm{L} 6-\mathrm{BA}$ increased the ratio of small bulblets.

\section{Discussion}

Lilium davidii var. unicolor is difficult to propagate by seeds because of its selfincompatibility. Therefore, increasing the number of bulbs of this plant mainly depends on vegetative propagation. Because L. davidii var. unicolor does not have bulbils, it can be increased from bulb division, stem bulblets, and bulb scales. The number of offsets is limited when propagating by bulb division and stem bulblets. Hence, these propagation methods are unable to meet the quantities of bulbs needed for extensive planting. Moreover, the spread of diseases has accelerated through these propagation approaches, leading to a significant decline in the quality and quantity of commercial bulbs in recent years. Scaling is the most cost-effective and rapid propagation method of increasing lily bulbs. Scale production has largely replaced bulb division and the use of stem bulblets. Due to the high propagation coefficient of this method, it is widely used in commercial operations. Scales can be planted directly in fields or after incubation. The direct planting method is seldom used in commercial operations due to the long propagation period required $(\approx 17$ weeks) and low propagation coefficient (20-40 bulblets per bulb). Compared with direct planting, the propagation period is reduced to 6 weeks by means of the incubation method, and $\approx 100$ bulblets can be ob- tained per bulb. In this study, the optimum incubation temperature for scale propagation of $L$. davidii var. unicolor was screened by comparing the incidence rate of scale rot, scale differentiation, and formation of bulblets under different temperatures. Moreover, the effects of $\mathrm{GA}_{3}$, NAA, and 6-BA were discussed to provide theoretical evidence for the application of plant growth regulators in the scale propagation of $L$. davidii var. unicolor.

The application of $\mathrm{GA}_{3}$, NAA, and 6-BA showed no significant influence on the differentiation rate of scales. $\mathrm{GA}_{3}$ was conducive to reducing the incidence of scale rot. However, treatment with $50 \mathrm{mg} / \mathrm{L}$ NAA and $2 \mathrm{mg} / \mathrm{L}$ 6-BA significantly increased the incidence of scale rot in the second week of propagation. Treatments with $100 \mathrm{mg} / \mathrm{L}$ NAA and $100 \mathrm{mg} / \mathrm{L} \mathrm{GA}_{3}$ produced a higher number of bulblets than their controls after 6 weeks of incubation. $\mathrm{GA}_{3}$ at 100 and $150 \mathrm{mg} / \mathrm{L}$ increased the diameter of bulblets, resulting in more large bulblets (grade 1) and fewer small bulblets (grade 3). 6-BA did not help to facilitate propagation by scaling.

Comparisons of different temperatures for scale propagation. Among the different reproduction methods for lily, propagation by bulb scales is the most cost-efficient and time-saving approach for increasing the number of bulbs. Although the scaling technique for Lilium was reported many years ago (Matsuo and Arisumi, 1980; Matsuo and van Tuyl, 1984; Matsuo et al., 1978), there is no complete study of the scale propagation system. Temperature is one of the most important factors in vegetative propagation. In this study, different temperatures were tested for scale propagation of $L$. davidii var. unicolor. The incidence of scale rot, bulbing potential, and number of bulblets under different temperature treatments were described.

The results of this study showed that temperature influences the incidence rate of scale rot, speed of scale differentiation, 
Table 3. Effects of different concentrations of $\mathrm{GA}_{3}$, NAA, and 6-BA on scale differentiation.

\begin{tabular}{|c|c|c|c|c|c|c|}
\hline & \multirow[b]{2}{*}{ Treatment } & \multicolumn{5}{|c|}{ Scale differentiation rate $(\%)( \pm \mathrm{SE})$} \\
\hline & & $2 \mathrm{wk}$ & $3 \mathrm{wk}$ & $4 \mathrm{wk}$ & $5 \mathrm{wk}$ & $6 \mathrm{wk}$ \\
\hline \multirow[t]{4}{*}{$\mathrm{GA}_{3}$} & CK & $20.33 \pm 8.38 \mathrm{a}$ & $41.98 \pm 1.64 \mathrm{a}$ & $35.11 \pm 11.27 \mathrm{~b}$ & $51.18 \pm 3.70 \mathrm{a}$ & $70.46 \pm 9.68 \mathrm{a}$ \\
\hline & $50 \mathrm{mg} / \mathrm{L}$ & $5.33 \pm 4.03 b$ & $39.21 \pm 10.67 \mathrm{a}$ & $51.09 \pm 2.81 \mathrm{ab}$ & $52.70 \pm 15.46 \mathrm{a}$ & $52.74 \pm 18.08 \mathrm{a}$ \\
\hline & $100 \mathrm{mg} / \mathrm{L}$ & $27.00 \pm 7.48 \mathrm{a}$ & $37.84 \pm 6.38 \mathrm{a}$ & $57.69 \pm 7.34 \mathrm{a}$ & $61.34 \pm 7.86 \mathrm{a}$ & $80.29 \pm 3.70 \mathrm{a}$ \\
\hline & $150 \mathrm{mg} / \mathrm{L}$ & $18.33 \pm 3.40 \mathrm{ab}$ & $43.09 \pm 6.71 \mathrm{a}$ & $62.93 \pm 7.41 \mathrm{a}$ & $58.03 \pm 8.72 \mathrm{a}$ & $63.73 \pm 10.92 \mathrm{a}$ \\
\hline \multirow[t]{4}{*}{ NAA } & CK & $24.67 \pm 3.68 b$ & $36.36 \pm 15.73 \mathrm{a}$ & $49.23 \pm 5.50 b$ & $61.71 \pm 6.59 \mathrm{a}$ & $70.99 \pm 9.79 \mathrm{a}$ \\
\hline & $50 \mathrm{mg} / \mathrm{L}$ & $14.33 \pm 8.58 b$ & $35.82 \pm 12.75 \mathrm{a}$ & $75.65 \pm 2.83 \mathrm{a}$ & $73.35 \pm 1.70 \mathrm{a}$ & $73.02 \pm 2.08 \mathrm{a}$ \\
\hline & $100 \mathrm{mg} / \mathrm{L}$ & $11.00 \pm 2.45 b$ & $56.64 \pm 1.29 \mathrm{a}$ & $56.14 \pm 9.66 b$ & $62.47 \pm 3.12 \mathrm{a}$ & $77.47 \pm 4.55 \mathrm{a}$ \\
\hline & $150 \mathrm{mg} / \mathrm{L}$ & $38.00 \pm 8.52 \mathrm{a}$ & $48.28 \pm 3.52 \mathrm{a}$ & $62.96 \pm 1.98 \mathrm{ab}$ & $72.05 \pm 1.32 \mathrm{a}$ & $72.13 \pm 2.07 \mathrm{a}$ \\
\hline \multirow[t]{4}{*}{$6-\mathrm{BA}$} & $\mathrm{CK}$ & $26.00 \pm 3.56 \mathrm{a}$ & $47.57 \pm 4.41 \mathrm{a}$ & $56.61 \pm 8.97 \mathrm{a}$ & $52.66 \pm 1.55 \mathrm{a}$ & $54.02 \pm 11.20 \mathrm{ab}$ \\
\hline & $1 \mathrm{mg} / \mathrm{L}$ & $12.33 \pm 4.50 b$ & $24.87 \pm 3.93 b$ & $42.43 \pm 6.23 \mathrm{a}$ & $40.55 \pm 2.72 \mathrm{a}$ & $43.13 \pm 5.27 b$ \\
\hline & $2 \mathrm{mg} / \mathrm{L}$ & $14.67 \pm 2.46 b$ & $34.86 \pm 16.54 \mathrm{ab}$ & $49.38 \pm 10.85 \mathrm{a}$ & $54.00 \pm 20.54 \mathrm{a}$ & $70.95 \pm 2.31 \mathrm{a}$ \\
\hline & $3 \mathrm{mg} / \mathrm{L}$ & $11.67 \pm 2.05 \mathrm{~b}$ & $29.61 \pm 5.41 \mathrm{ab}$ & $44.11 \pm 3.84 \mathrm{a}$ & $49.89 \pm 5.82 \mathrm{a}$ & $45.48 \pm 5.31 \mathrm{~b}$ \\
\hline
\end{tabular}

The different lowercase letters indicate significant differences at $P<0.05$ level.

Table 4. Effects of different concentrations of $\mathrm{GA}_{3}$, NAA, and 6-BA on number of bulblets.

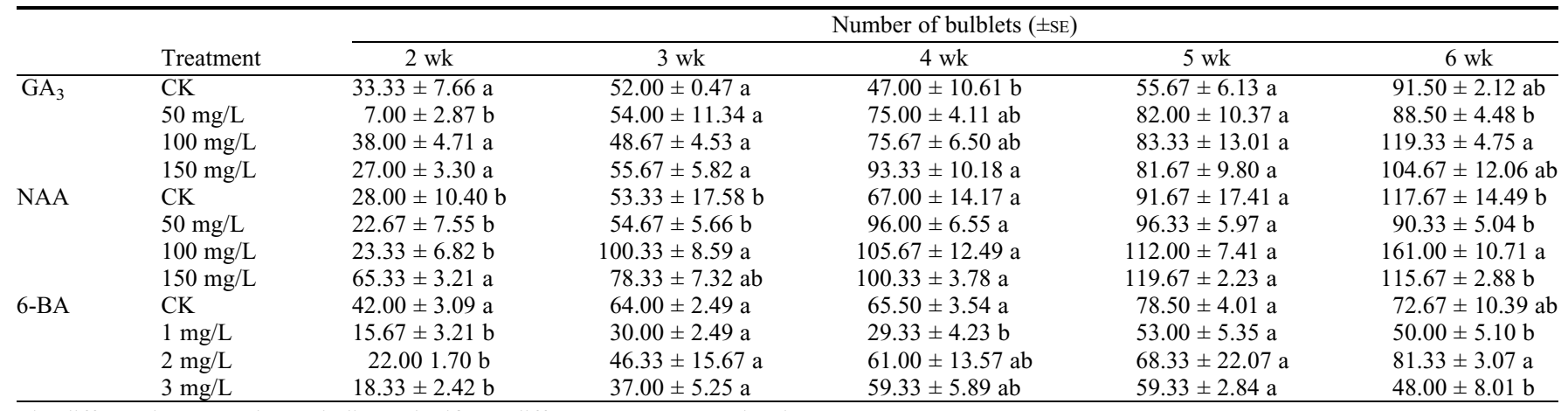

The different lowercase letters indicate significant differences at $P<0.05$ level.

and bulblet formation, as well as the size of the bulblets. The optimum temperature for scale propagation of $L$. davidii var. unicolor was $30{ }^{\circ} \mathrm{C}$. Scales incubated at $30{ }^{\circ} \mathrm{C}$ showed a lower rot incidence rate, faster differentiation, and larger bulblets.

The incidence of scale rot is important in scaling propagation. At the beginning of scale propagation, the edges of the scales became yellow or brown. This phenomenon had little influence on the production of bulblets because most of the scales can selfheal. However, some of the scales showed increasingly serious conditions, showing larger and darker spots and even rot. Once the scales experienced rot, it was difficult to obtain a healthy bulblet. Temperature has an important role during this process. The results of this study showed that the rot incidence rates of scales incubated at 25 and $30{ }^{\circ} \mathrm{C}$ were significantly lower than that of scales incubated at $20^{\circ} \mathrm{C}$. Relatively high temperatures are beneficial for rot control during scale incubation in peat. It is known that the formation of callus can effectively prevent pathogen infection. Wounding promotes callus formation in various parts of plants (Ikeuchi et al., 2013). During scale propagation, wounds on the basal part of scales produce calli. The faster the callus induced in the scale, the better the control of scale rot. The growth of calli requires a suitable temperature, and too low or too high temperatures are not good (Liu et al., 2010). Wound-induced calli regenerate new organs or new tissues due to their pluripotency (Stobbe et al., 2002).

Obtaining a large amount of bulblets is the ultimate goal of reproduction. The differentiation rate of scales and number of bulblets per scale are important indices for evaluating reproductive effectiveness. According to a previous study, $\approx 4$ weeks are needed to complete differentiation during propagation of lilies by scales (Marinangeli et al., 2003). In this study, lily scales started to differentiate soon after the propagation process started. Bulblets formed rapidly during the first 3 weeks. Scales cultured at 25 and $30{ }^{\circ} \mathrm{C}$ differentiated faster than scales cultured at $20^{\circ} \mathrm{C}$. If time is limited, then fast propagation could be achieved through incubation at $30{ }^{\circ} \mathrm{C}$, at which only 3 weeks were needed to reach the highest differentiation rate of scales. There was no significant difference in the amount of bulblets obtained at the sixth week of scale propagation among different temperature treatments. However, the shorter the incubation time, the higher the reproductive efficiency. At 30 or $25^{\circ} \mathrm{C}$, only 3 weeks were needed to obtain the largest number of bulblets. Therefore, the entire propagation process was shortened.

Effects of plant growth regulators on scale propagation. Plant growth regulators have been widely used for plant cutting propagation for years (Blythe et al., 2004; Schwarz, 1987). In this study, bulb scales of L. davidii var. unicolor were treated with different concentrations of $\mathrm{GA}_{3}, \mathrm{NAA}$, and
6-BA to explore their influence on scale propagation. It was observed that a high concentration of $\mathrm{GA}_{3}$ was conducive to self-healing of scales, which was probably related to the growth of calli. Murashige (1965) reported that $\mathrm{GA}_{3}$ could inhibit organogenesis and stimulate callus growth. Although JA is a wound hormone of terrestrial plants, it is not the only hormone that promotes plant self-healing; cross-talk between JA and other hormone signaling pathways, such as that of gibberellin, also has an important role (Kazan and Manners, 2012). However, $50 \mathrm{mg} / \mathrm{L}$ NAA and $2 \mathrm{mg} / \mathrm{L}$ 6-BA had negative effects on scale propagation in this study, resulting in a notably high scale rot incidence. This agrees with a previous study that reported that the percentage of rotten scales was high for NAA-treated scales of lily (Liu et al., 2006). Hence, extreme caution is needed for the application of NAA in scale propagation.

$\mathrm{GA}_{3}$, NAA, and 6-BA were not conducive to promoting scale differentiation of $L$. davidii var. unicolor. This is similar to a previous study of Hippeastrum vittatum, which found that $\mathrm{GA}_{3}$, IBA, and NAA did not result in scale propagation and bulblet development (Zhang et al., 2013). In particular, $100 \mathrm{mg} / \mathrm{L}$ NAA significantly increased the amount of bulblets. Simmonds and Cumming (1976) developed a method for the large-scale propagation of lilies by callus induced from bulb scales. The maximum amount of plantlets was obtained on agar medium with NAA 

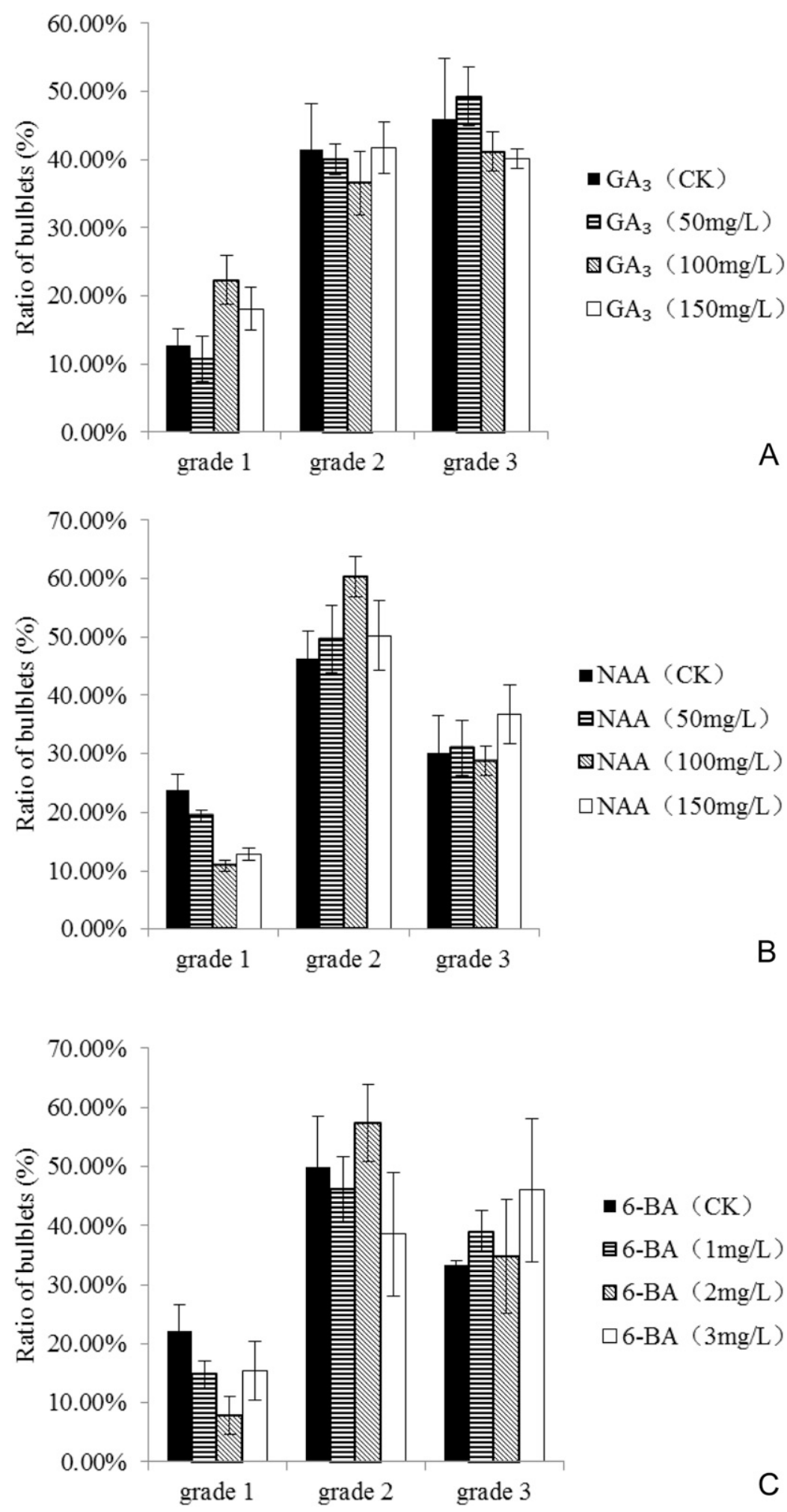

Fig. 4. Effects of plant growth regulators on the size of bulblets produced. Effects of $\mathrm{GA}_{3}(\mathbf{A}), \mathrm{NAA}(\mathbf{B})$, and 6-BA (C) are shown. Values represent the mean of three independent replicates. Bars indicate the SE.

treatment. Huang et al. (2005) reported that NAA significantly increased the number of bulblets in the cutting propagation of hybrid lily.

In this study, scales treated with 100 and $150 \mathrm{mg} / \mathrm{L} \mathrm{GA}_{3}$ produced more large bulblets, indicating that a certain concentration of $\mathrm{GA}_{3}$ treatment was beneficial for obtaining larger bulblets. This result was consistent with that found by Sun (2009). However, Hank and Rees (1977) found that gibberellic acid reduced the number and weight of bulbils produced by twin-scaling of narcissus, whereas abscisic acid, indol3 -ylacetic acid, and kinetin increased the weight of bulbils. In general, scales treated with $100 \mathrm{mg} / \mathrm{L} \mathrm{GA}_{3}$ and incubated at $30{ }^{\circ} \mathrm{C}$ performed best.

\section{Literature Cited}

Aklade, S.A., K. Bardhan, P. Singh, D.K. Kakade, and A.B. Pathan. 2009. Effect of PGR's on growth, flowering and flower yield of chrysanthemum (Chrysanthemum indicum $\mathrm{L}$.) cv. 'LOCAL WHITE'. Asian J. Hort. 4(2):491-493.

Austin-McRae, E. 1998. Lilies: A guide for growers and collectors. Timber Press, Portland, OR.

Blythe, E.K., J.L. Sibley, J.M. Ruter, and K.M. Tilt. 2004. Cutting propagation of foliage crops using a foliar application of auxin. Scientia Hort. 103(1):31-37.

Cleland, R.E. 2010. Auxin and cell elongation, p. 214-227. In: P.J. Davies (ed.). Plant hormones. Springer, Dordrecht.

Dicks, J.W., J.M. Gilford, and A.R. Rees. 1973. The influence of timing of application and gibberellic acid on the effects of ancymidol on growth and flowering of mid-century hybrid lily cv. Enchantment. Scientia Hort. 2:153-163.

Dilta, B.S., N.S. Pathania, and O.P. Sehgal. 2000 Studies on scale propagation of hybrid lilies. J. Ornam. Hort. 3(1):62-63.

Finkelstein, R.R. 2010. The role of hormones during seed development and germination, p. 549-573. In: P.J. Davies (ed.). Plant hormones. Springer, Dordrecht.

Gaspar, T., C. Kevers, C. Penel, H. Greppin, D.M. Reid, and T.A. Thorpe. 1996. Plant hormones and plant growth regulators in plant tissue culture. Vitro Cellular \& Developmental Biology Plant. 32(4):272-289.

Hanks, G.R. and A.R. Rees. 1977. Growth regulator treatments to improve the yield of twinscaled narcissus. Scientia Hort. 6(3):237-240.

Huang, Y., H. Chen, J.Y. Liu, and Z.J. Wang. 2005. Study on cutting propagation of bud scale of oriental hybrid lily. Chinese Agr. Sci. Bul. 21(10):273-275.

Ikeuchi, M., K. Sugimoto, and A. Iwase. 2013. Plant callus: Mechanisms of induction and repression. Plant Cell 25(9):3159-3173.

Ishimori, T. and Y. Niimi. 2005. Similar effects of colchicine and low temperature on initiation and elongation of stems in bulblets developed on scales of 'White Aga' (Lilium $\mathrm{x}$ formolongi) cultured in vitro. IX International Symposium on Flower Bulbs. Acta Hort. doi: 10.17660/ ActaHortic.2005.673.51.

Ishimori, T., Y. Niimi, and D.S. Han. 2007 Benzyladenine and low temperature promote phase transition from juvenile to vegetative adult in bulblets of Lilium. Plant Cell Tissue \& Organ Culture 88:313-318.

Kawa-Miszczak, L., E. Wegrzynowicz, and M. Saniewski. 1992. The effect of removal of roots and application of plant growth regulators on tulip shoot growth. Acta Hort. 325:71-76.

Kazan, K. and J.M. Manners. 2012. JAZ repressors and the orchestration of phytohormone crosstalk. Trends Plant Sci. 17(1):22-31.

Khan, F.U., F.A. Malik, F.A. Khan, and M.A.A Siddique. 2007. Effect of plant growth regulators on growth, physiological behaviour and flower quality of 'Cassini' tulip (Tulipa gesneriana). Indian J. Agr. Sci. 77(10):695-697.

Kumar, S., D.R. Sharma, and J.K. Kanwar. 2006. In vitro propagation of Lilium. Adv. Hort. Sci. 20(2):181-188.

Kumar, S., V. Chaudhary, and J.K. Kanwar. 2008. In vitro propagation of oriental hybrid lily from root explant. Adv. Hort. Sci. 22(1):63-65. 
Liu, F.J., H.M. Sun, and Y.H. Tian. 2006. Effects of plant growth regulators on scale propagation in lily. Northern Hort. 30(1):40-42.

Liu, Y.M., Y.M. Liu, M. Ma, and B.H. He. 2010 Influence of culture conditions on the growth of callus and content of total flavonoids in Acer buergerianum Miq. J. Beijing For. Univ. 32(1):142-146.

Marinangeli, P.A., L.F. Hernández, C.P. Pellegrini, and N.R. Curvetto. 2003. Bulblet differentiation after scale propagation of Lilium longiflorum. J. Amer. Soc. Hort. Sci. 128:324-329.

Matsuo, E., A. Nonaka, and K.I. Arisumi. 1978. Studies on the leaf development of the scale bulblet in the easter lily (Lilium longiflorum Thunb.): 2. Relationship between the size of the parent bulb or the parent scale and the type of leaf development (plant type). Gakujutsu Hokoku Bul. 46(4):515-520.

Matsuo, E. and K.I. Arisumi. 1980. Studies on growth and development of bulbs in the easter lily (Lilium longiflorum Thunb.): X. Dry weight change of parent scale or newly formed plantlet during dark incubation. J. Jpn. Soc. Hort. Sci. 49(3):409-413.

Matsuo, E., M. Matsuzawa, Y. Sakata, and K. Arisumi. 1989. Asexual propagation of variegated Lilium longiflorum 'Chotaro'. Scientia Hort. 39(4):349-354.

Matsuo, E. and J.M. van Tuyl. 1984. Effect of bulb storage temperature on leaf emergence and plant development during scale propagation of Lilium longiflorum 'White American'. Scientia Hort. 24(1):59-66.
Murashige, T. 1965. Effects of stem-elongation retardants and gibberellin on callus growth and organ formation in tobacco tissue culture. Physiol. Plant. 18(3):665-673.

Prat, S. 2010. Hormonal and daylength control of potato tuberization, p. 574-596. In: P.J. Davies (ed.). Plant hormones. Springer, Dordrecht.

Schwarz, O.J. 1987. Plant growth regulator effects in the in vitro propagation of three hardwood tree genera: Castanea, Juglans, and Quercus. Plant Growth Regulat. 6(1):113-135.

Simmonds, J.A. and B.G. Cumming. 1976. Propagation of Lilium hybrids. II. Production of plantlets from bulb-scale callus cultures for increased propagation rates. Scientia Hort. 5(2): 161-170.

Stobbe, H., U. Schmitt, D. Eckstein, and D. Dujesiefken. 2002. Developmental stages and fine structure of surface callus formed after debarking of living lime trees (Tilia sp.). Ann. Bot. 89(6):773-782.

Sun, H.M. 2009. Effects of sawdust, peat, $\mathrm{GA}_{3}$ and IBA on scale cutting propagation in Lilium davidii var. unicolor. J. Shenyang Agr. Univ. 40(2):160-164.

Tian, X., J. Xie, and J. Yu. 2020. Physiological and transcriptomic responses of Lanzhou Lily (Lilium davidii var. unicolor) to cold stress. PLoS One 15:e0227921, doi: 10.1371/ journal.pone.0227921.

Woodger, F., J.V. Jacobsen, and F. Gubler. 2010. Gibberellin action in germinated cereal grains, p. 221-240. In: P.J. Davies (ed.). Plant hormones. Springer, Dordrecht.
Wu, Y., Y.P. Xia, J.P. Zhang, F. Du, L. Zhang, Y.D. Ma, and H. Zhou. 2016. Low humic acids promote in vitro lily bulblet enlargement by enhancing roots growth and carbohydrate metabolism. J. Zhejiang Univ. Sci. B 17(11):892904.

Xu, R.Y., Y. Niimi, and K. Kojima. 2007. Exogenous $\mathrm{GA}_{3}$ overcomes bud deterioration in tulip (Tulipa gesneriana L.) bulbs during dry storage by promoting endogenous IAA activity in the internodes. Plant Growth Regulat. 52(1):1-8.

You, X.J., C.Y. Xie, K.L. Liu, and Z.X. Gu. 2010. Isolation of non-starch polysaccharides from bulb of tiger lily (Lilium lancifolium Thunb.) with fermentation of Saccharomyces cerevisiae. Carbohydr. Polym. 81(1):35-40.

Zhang, W., L.N. Song, J.A. Teixeira da Silva, and H.M. Sun. 2013. Effects of temperature, plant growth regulators and substrates and changes in carbohydrate content during bulblet formation by twin scale propagation in Hippeastrum vittatum 'Red lion'. Scientia Hort. 160:230-237.

Zhang, J., Y.X. Gao, X.J. Zhou, L.P. Hu, and T.Z. Xie. 2010. Chemical characterisation of polysaccharides from Lilium davidii. Nat. Prod. Res. 24(4):357-369.

Zhao, H.T., C. Liu, J. Ming, and M. Ding. 2010 Effects of ABA on the development and dormancy in the bulblets of oriental hybrids lily 'Siberia' generated in vitro. Acta Hort. Sinica 37:428-434. 